JOANNA KOZIELSKA

Uniwersytet im. Adama Mickiewicza

w Poznaniu

\title{
PERSPEKTYWY I NOWE ROZWIAZZANIA W DORADZTWIE ZAWODOWYM. COACHING JAKO NARZĘDZIE PRACY DORADCÓW ZAWODOWYCH W KONTEKŚCIE IDEI LIFELONG LEARNINGU
}

\begin{abstract}
Kozielska Joanna, Perspektywy i nowe rozwiazania w doradztwie zawodowym. Coaching jako narzędzie pracy doradców zawodowych w kontekście idei lifelong learningu [Perspectives and New Solutions in Guidance Counseling. Coaching as a Tool of Guidance Counselors Work in the Context of the Idea of Lifelong Learning]. Studia Edukacyjne nr 37, 2015, Poznań 2015, pp. 169-192. Adam Mickiewicz University Press. ISBN 978-83-232-2967-4. ISSN 1233-6688. DOI: 10.14746/se.2015.37.11
\end{abstract}

The requirement of lifelong learning has become a feature of our times, to the indeterminate nature, volatility and the need to respond to changing living conditions. Career models (Multi-vectored unstable), so different than those before the transformation period, indicate that the search for employment, its changing and adapting to the current socio - economic situation has become today's challenge and task of a lifetime. Others, according to the author, the consequences are "necessary changes in the education system teleology. The aims and objectives of the educational system must be much more accentuated: air motivation to learn, triggering willingness and readiness to further learning, developing the ability to pursue interests and passions, developing independent learning skills, with proper self-monitoring and evaluation of their work by learners" (Wróblewska, 2006). Coaching is a method of work, which is based precisely on these indications. It is successfully used in the education system and counselling. In the context of a rapidly changing social reality, coaching has become a method of work that provides customer skills, which then can be used in everyday life, transforming from a person's extra-control to self-control. In a world where algorithms, paradigms proceedings wane in importance to the multiplicity of social transformation and alternating tomorrow, you need to change from the teaching of the universal forms of behavior in specific situations to the teaching of specific forms of behavior in an imprecise reality. Coaching behavior may be a response to this demand.

Key words: coaching, education, career coaching, lifelong learning, career counseling 


\section{Wstęp}

Zapotrzebowanie na profesjonalną pomoc w świecie płynnej nowoczesności nie maleje. Jest wręcz przeciwnie, zapotrzebowanie to wzrasta wprost proporcjonalnie do złożoności dzisiejszej codzienności, wzrastającego poczucia bezradności, zagubienia w chaosie codziennych zmagań. Niepewność jutra, nieprzewidywalność współczesnego świata, mnogość poglądów, mglistość życiowych norm i wartości, które można by uczynić drogowskazami w życiu powodują, że trudno dziś sobie poradzić z problemami dnia codziennego. Nie dziwi zatem fakt, iż obserwujemy eksplozję aktywności doradców, konsultantów, trenerów, terapeutów, mentorów, tutorów, mówców motywacyjnych, czy coachów. W ostatnim czasie pojawiło się bardzo wiele publikacji na temat coachingu, można nawet rzec, iż zapanował coachingowy boom czy moda. Nietrudno odnaleźć także oferty szkoleń czy studiów o tej tematyce oraz branżowe coachingowe magazyny ${ }^{1}$. Pojawiło się także wiele definicji terminu coaching; słowo to stało się słowem-kluczem, słowem-magicznym zaklęciem, słowem-wytrychem mającym otworzyć wiele drzwi. Niewątpliwie przyniosło to terminologiczny chaos, a także wpłynęło na osłabienie naukowej wartości tej metody pracy. Jakkolwiek już teraz istnieje wiele dostępnych naukowych badań dowodzących o skuteczności coachingowych metod, należy wspomnieć choćby o analizach dokonanych prze Ingę Bielińską (ICF), która zestawia poczynione $w$ tej dziedzinie weryfikacje empiryczne ${ }^{2}$. Z przeprowadzonych w 2008 roku przez Price Water House Coopers, na zlecenie International Coach Federation, weryfikacji, w których udział wzięło 2165 osób z 64. krajów, wynika, iż klienci coachingu wskazali poprawę w takich obszarach, jak: pewność siebie $(80 \%)$, związki (73\%), kompetencje komunikacyjne $(72 \%)$, kompetencje interpersonalne (71\%), wydajność w pracy (70\%), równowaga życia zawodowego i osobistego $(67 \%)$, zdrowie, dobre samopoczucie $(63 \%)$, rozwój życia zawodowego, nowe możliwości zawodowe (62\%), organizacja życia osobistego $(61 \%)$, zarządzanie firmą $(61 \%)$, zarządzanie czasem (57\%), efektywność zespołów

1 Za przykład niech posłużą publikacje: L. Kupaj, W. Krysa, Kompetencje coachingowe nauczycieli. Jak rozwijać potencjał ucznia w szkole, Warszawa 2014; J. Whitmore, Coaching. Trening efektywności, Warszawa 2009; M. Bennewicz, Coaching, czyli restauracja osobowości, Warszawa 2013; tegoż, Coaching przebudzacz neuronów, Warszawa 2009; M. Sidor-Rządkowska (red.), Coaching. Teoria, praktyka, studia przypadków, Warszawa 2009; J. Bałachowicz, A. Rowicka, Nowoczesny wychowawca - tutor, mentor, coach, Warszawa 2013, s. 24-37, 37-44, 160-168; K. Blanchard, D. Shula, Coaching. Prowadź swoją drużynę ku zwycięstwu, Warszawa 2009; S. Thorpe, J. Clifford, Podręcznik coachingu, Poznań 2004 i inne.

2 I. Bielińska, Badania skuteczności coachingu, tekst dostępny na http://ingabielinska.com/ coaching-dla-firm/badania-skutecznosci-coachingu/ [dostęp: 10.10.15]. 
(51\%). Według badań firmy A Better Perspective ${ }^{\mathrm{TM}}$, zrealizowanych w 2009 roku na reprezentatywnej grupie składającej się 339 osób, które skorzystały z coachingu lub/i były jego zleceniodawcami dla innych, główne korzyści $\mathrm{z}$ coachingu to: poprawa $\mathrm{w}$ wydajności osobistej i realizacji celów $(84 \%)$, podniesienie otwartości na rozwój osobisty i uczenie się $(60 \%)$, pomoc w znalezieniu rozwiązania dla poszczególnych sytuacji zawodowych (58\%), wzmocnienie poczucia odpowiedzialności $(52 \%)$, rozwój samoświadomości $(42 \%)$, wzmocnienie pożądanych umiejętności i zachowań $(38 \%)$, lepsze rozumienie roli i celów $(37 \%)$, korekta zachowań i wyjaśnienie trudności (33\%). Na podstawie rankingu stu spółek (Fortune 100), „The Economic Times" przedstawił raport, że dzięki coachingowi w firmach, ROI (zwrot z inwestycji) jest prawie sześć razy większe, niż koszty wprowadzenia programu szkoleniowego, $\mathrm{w}$ tym: o $77 \%$ poprawiają się relacje między pracownikami, o $67 \%$ wzrasta efektywność pracy zespołowej, o 61\% wzrasta satysfakcja $\mathrm{z}$ wykonywanej pracy. Z kolei, badanie przeprowadzone na 500 spółkach branży telekomunikacyjnej z listy rankingowej Fortune 500 wykazało, że wprowadzenie coachingu w firmach może podnieść wskaźnik rentowności przedsiębiorstwa nawet do 529\%. Programy szkoleniowo-coachingowe podwyższają produktywność menadżerów czterokrotnie bardziej niż same szkolenia. Podczas gdy szkolenia podwyższyły produktywność menadżerów o $22 \%$, to po rozszerzeniu programu szkoleniowego o 8 indywidualnych sesji coachingu, produktywność menadżerów wzrosła o $88 \%$. Doniesienia $\mathrm{z}$ biznesowego świata o jego kooperacji z coachingiem są optymistyczne; coaching w biznesie zagościł po tym, jak odniósł sukces w świecie sportu, więc tym bardziej wydaje się prawdopodobne, że jego transmisja nastąpi dalej do systemu edukacji i wewnątrzszkolnego systemu doradztwa zawodowego, jak i urzędów pracy oraz ośrodków pomocy społecznej, także przyczyniając się do wieloaspektowych pozytywnych zmian.

Jak podkreśla P.J. Sutton, na co w swoim opracowaniu wskazuje W. Wróblewska (2006), edukacja ustawiczna jest „otwarta na różne interpretacje, często rozumienie tego pojęcia jest uzależnione od perspektywy filozoficznej lub politycznej indywidualnego autora lub organizacji" 3 . Można wyodrębnić kilka cech wspólnych koncepcji kształcenia ustawicznego, kształcenia się w toku życia: 1) pragnienie powszechnego dostępu do edukacji, obejmującej swoim zasięgiem dzieci i dorosłych, którzy obecnie mają utrudnione możliwości kształcenia; 2) uznanie wagi usytuowania edukacji poza instytucjami formalnymi; 3) różnorodność materiałów do uczenia

${ }^{3}$ W. Wróblewska, Konsekwencje zatożeń koncepcji edukacji ustawicznej dla autoedukacji, 2006; tekst dostępny na: http://www.e-mentor.edu.pl/artykul/index/numer/17/id/356/ [dostęp: maj 2015]. 
się; 4) wspieranie i kształtowanie u uczniów cech osobowych przydatnych w procesie ciągłego uczenia się, motywacji i zdolności niezbędnych do podejmowania samokształcenia. Zawierające się w pojęciu edukacji ustawicznej uczenie się ma „umożliwić każdej jednostce dalsze rozwijanie swojego fizycznego, psychicznego, emocjonalnego i intelektualnego potencjału"4.

Wymóg całożyciowego kształcenia się stał się cechą naszych czasów, wobec ich niedookreśloności, zmienności i potrzeby reagowania na zmieniające się warunki życia. Modele kariery (wielowektorowe, niestabilne), tak różne od tych sprzed okresu transformacji ustrojowej, wskazują, iż poszukiwanie zatrudnienia, jego zmienianie i dostosowywanie do aktualnej sytuacji społeczno-gospodarczej stało się dziś wyzwaniem i zadaniem na całe życie. Innymi, jak podaje autorka, konsekwencjami są

potrzeby przemian $\mathrm{w}$ teleologii systemu kształcenia. $\mathrm{W}$ zakresie celów i zadań systemu edukacyjnego $\mathrm{w}$ większym stopniu należy akcentować: budzenie motywacji uczenia się, wyzwalanie chęci i gotowości do dalszej nauki, kształtowanie umiejętności realizowania zainteresowań i zamiłowań, kształtowanie umiejętności samodzielnego uczenia się, z właściwą autokontrolą i oceną swej pracy przez uczących się̧5.

Coaching stanowi metodę pracy opierającą się właśnie na powyższych wskazaniach. $Z$ powodzeniem jest wykorzystywany $\mathrm{w}$ systemie edukacji oraz przez doradców zawodowych. W realiach szybko zmieniającej się rzeczywistości społecznej stając się metodą pracy, wyposaża klienta w umiejętności, które następnie może wykorzystać on w życiu codziennym, przeobrażając się z osoby zewnątrz- na wewnątrzsterowną. W świecie, gdzie algorytmy, paradygmaty postępowań słabną na znaczeniu wobec wielości społecznych przeobrażeń i zmiennego jutra, potrzebna jest zmiana przebiegająca od nauczania uniwersalnych form zachowań w określonych sytuacjach w kierunku nauczania specyficznych form zachowań w niedookreślonej rzeczywistości. Coachingowe postępowanie może być na to zapotrzebowanie odpowiedzią6.

W związku z powyższym, intencją autorki niniejszego tekstu jest przedstawienie terminologicznych rozróżnień mocujących coaching na właściwym miejscu, a w dalszej części opisanie trudności związanych z praktycznym stosowaniem coachingowych metod $w$ systemie edukacji oraz instytucjach zajmujących się doradztwem zawodowym i nie tylko, jak też

4 Tamże.

5 Tamże.

${ }^{6}$ J. Kozielska, Coaching w edukacji, Uczyć Lepiej, 2015/2016, 1; J. Kozielska, A. SkowrońskaPućka, Coaching czym jest a czym nie jest? O możliwościach wykorzystania coachingu jako niedyrektywnej formy wspierania w systemie edukacji, [w:] Dymensje poradnictwa $i$ wsparcia społecznego w perspektywie interdyscyplinarnej, red. M. Piorunek, Poznań 2015, s. 19-36; tychże, O możliwościach wykorzystania coachingu w edukacji, Uczyć Lepiej, 2013/2014, 5. 
zaprezentowanie jednego $\mathrm{z}$ modeli do praktycznego zastosowania $\mathrm{w}$ doradztwie zawodowym. Na zakończenie ukazane zostaną korzyści, jakie może przynieść stosowanie tej metody.

\section{Coaching - zarys historyczny i terminologiczny}

Coaching to forma pracy ukształtowana za sprawą kilku pionierów szkół psychoterapii i poradnictwa. $\mathrm{W}$ historii nauki pierwszy terminu coaching (psychology of coaching) użył amerykański psycholog sportu Coleman R. Griffith, który w 1926 roku opublikował książkę zatytułowaną The Psychology of Coaching. A Study of Coaching Methods from the Point of Psychology. Rozważania autora są jednak wypadkową nurtu psychoanalizy i behawioryzmu (XIX i XX wiek), rewolucji poznawczej (Albert Ellis, Aaron Beck), psychologii humanistycznej (Carl Rogers, Abraham Maslow), czy wreszcie nowej szkoły psychoterapii (Gestalt, Eriksonowska systemówka). To u ich podłoża odnajdujemy coachingowe postulaty pracy na przekonaniach, relacji, rozwoju potencjału, obustronnego szacunku klient-terapeuta, czy wreszcie niedyrektywności w pomaganiu. Należy zaznaczyć, iż na obecny kształt modelu coachingowego wpłynęły także rozważania psychologii organizacji, counsellingu oraz psychologii sportu ${ }^{7}$.

Jak podaje International Coach Federation:

Coaching jest interaktywnym procesem, który pomaga pojedynczym osobom lub organizacjom w przyspieszeniu tempa rozwoju i polepszeniu efektów działania. Coachowie pracują $\mathrm{z}$ klientami $\mathrm{w}$ zakresach związanych $\mathrm{z}$ biznesem, rozwojem kariery, finansami, zdrowiem i relacjami interpersonalnymi. Dzięki coachingowi klienci ustalają konkretniejsze cele, optymalizują swoje działania, podejmują trafniejsze decyzje i pełniej korzystają ze swoich naturalnych umiejętności. Profesjonalni coachowie zapewniają nieustającą współpracę przygotowaną specjalnie w celu niesienia pomocy klientom w osiąganiu satysfakcjonujących rezultatów w ich życiu zawodowym i osobistym. Coachowie pomagają ludziom poprawiać ich osiągnięcia i podnosić jakość ich życia. Są oni nauczeni słuchania, obserwowania i przystosowywania własnego podejścia do indywidualnych potrzeb klienta. Dążą do wydobycia rozwiązań i strategii z wnętrza klienta. Wierzą, że klient jest z natury kreatywny i pełen pomysłów. Zadanie coacha polega na wydobyciu tych umiejętności, zasobów i kreatywności, które klient już posiada9.

${ }^{7}$ A. Zemełka, Coaching jako niedyrektywna forma wsparcia rozwoju - inspiracje i perspektywy, [w:] Dymensje poradnictwa, s. 19-37.

8 Międzynarodowa Federacja Coachów z siedzibą także w Polsce i każdym większym polskim mieście, www.icf.pl; ICF - coaching http://icf.org.pl/pl79,coaching.html [dostęp: luty 2014].

${ }^{9}$ Tamże. 
International Coaching Community opisuje coaching jako wieloetapowy proces rozwoju, polegający na wzmacnianiu samoświadomości klienta, podejmowaniu przez niego odpowiedzialności za dany obszar życia i samodzielne dokonywanie zmian. Coaching pomaga klientom stawać się tym kim chcą być, u jego podłoża leżą partnerskie relacje i zaufanie ${ }^{10}$. Skutkiem coachingowego procesu jest, jak twierdzi Marek Podgórny, odblokowanie potencjału jednostki, co dokonuje się poprzez „trening refleksyjności nad sobą i otoczeniem oraz przez uczenie się nowych umiejętności", owa refleksyjność prowadząca do samorozwoju dzięki pokonywaniu kolejnych tranzycji staje się podstawą do konstruowania tożsamości oraz do budowania korzystnych warunków życia ${ }^{11}$.

Wspólnym elementem każdej z definicji jest to, iż coaching to proces o ustrukturalizowanej formule, mający na celu samodzielne osiągniecie przez coachee (klienta) skonkretyzowanej zmiany, będącej rezultatem odkrywania swoich zasobów, oparty na wzajemnym szacunku, zaufaniu i partnerstwie w relacji coach-coachee.

Terminologiczny chaos wynika być może z faktu, że coachingiem nazywa się wciąż jeszcze wiele różnych metod pracy (o czym poniżej), podczas gdy mają one swoje oddzielne, specyficzne nazwy. Niepokój budzą także sytuacje, w których trenerzy czy szkoleniowcy określają się mianem coachów, traktując te terminy jako synonimy.

Analizując historię coachingu, można stwierdzić, że

jako dziedzina nauki i praktyki, osiągnął kluczowy punkt rozwoju, a zawód coacha wymaga ustalenia, jakie kompetencje są mu niezbędne. Profesjonalny coaching ma na celu wspieranie klienta w procesie samokształcenia i rozwoju osobistego, dlatego należy położyć nacisk na aspekty, które są za te efekty odpowiedzialne. Ponadto należy pamiętać, że coaching ze względu na swoją specyfikę i brak jednego modelu opisującego profesjonalny proces coachingowy ma w swoim spektrum wiele podejść teoretycznych ${ }^{12}$.

Coaching, na co wskazano powyżej, jest nierozerwalnie powiązany ze znaczną liczbą teorii psychologicznych, ponieważ nieustannie toczy się spór o wybór najtrafniej dopasowanych podstaw naukowych mogących stanowić dla niego podbudowę teoretyczną ${ }^{13}$.

${ }^{10}$ ICC - http:/ / encyklopediacoachingu.pl/haslo53, [dostęp: luty 2015].

11 M. Podgórny, Coaching jako forma wspierania procesu wiedza osobistą, [w:] Dymensje poradnictwa, s. 69-81.

12 Z. Nieckarz, S. Celińska-Nieckarz, D. Godlewska-Werner, Psychologia coachingu biznesowego, Harmonia Universalis, 2013, 11, s. 30.

13 Tamże, s. 32. 
Należy wymienić kilka projektów podejścia do coachingu:

- poznawczo-behawioralne - zakłada, że emocje pojawiające się u człowieka w konkretnej sytuacji są skutkiem jego opinii i dokonanej przez niego interpretacji zdarzenia, a nie sytuacji samej w sobie. Popełnione błędy, zniekształcenia $\mathrm{w}$ procesie oceny danego zdarzenia zakłócają proces wyboru adekwatnego zachowania się, przez co spada skuteczność działania jednostki. Proces coachingowy polega wobec powyższego na rozwijaniu samoświadomości osoby coachowanej i jej lepszego wglądu we własne myśli oraz uczucia, w określonych sytuacjach;

- perspektywa psychodynamiczna - uznaje z kolei, że ludzie zupełnie nie są świadomi mechanizmów, które znacząco wpływają na jakość ich życia. Ponieważ mają one swoje źródła w przeszłości człowieka, niezbędne jest poznanie tych mechanizmów poprzez skupienie się na ukrytych i/lub niechcianych uczuciach. Coach tworzy przestrzeń dla emocjonalnego otwarcia się klienta tak, aby dać mu możliwość akceptacji negatywnych doświadczeń z przeszłości, utrudniających mu rozwój i rozumienie siebie w chwili obecnej;

- perspektywa psychologii pozytywnej - stanowi natomiast, że psychologia pozytywna może się stać odpowiedzią na pytanie o naukowe, teoretyczne - będące jednak ważką częścią empirycznych dociekań - podstawy coachingu i ich egzemplifikację $\mathrm{w}$ postaci postulatów co do stosowania określonych narzędzi oraz metod psychometrycznych. Jednym z obszarów zainteresowań psychologii pozytywnej jest optymalny rozwój jednostki, jej dążenie do doskonałości ${ }^{14}$.

Niezależnie od podejścia przyjmuje się, że „skuteczny coaching będzie miał efekt piorunujący w postaci pozytywnych zmian, które dotyczyć będą nie tylko osoby bezpośrednio poddanej coachingowi, lecz również jej otoczenia"15. Jedną z metod $\mathrm{w}$ pracy coacha jest praca $\mathrm{z}$ metaforą, dlatego podsumowując teoretyczne rozważania dotyczące definicji i koncepcyjnych źródeł coachingu nie mogło zabraknąć opowieści jednego z ojców coachingu M. Eriksona:

Pewnego dnia na podwórko gospodarstwa, w którym zamieszkiwatem będac dzieckiem, przywędrowat nieznany koń. Nikt nie wiedziat skąd przybyl, a nie miat na sobie żadnego oznaczenia, które mogłoby nam pomóc ustalić jego pochodzenie. Nie mogło być mowy o zatrzymaniu konia, ponieważ z pewnościa do kogoś należat. Mój ojciec zdecydowat odprowadzić go do domu. Wsiadt na niego, wyprowadzit go na droge i po prostu zaufat, że instynkt konia zawiedzie go do jego domu. Interweniowat jedynie wtedy, gdy kon schodzit $z$ drogi i zaczynat jeść trawę, albo zbaczat

14 Tamże, s. 29-45.

${ }^{15}$ D. Clutterbuck, Coaching zespotowy, Poznań 2009, s. 15. 
w pola. Wówczas ojciec prowadził go z powrotem na drogę. W ten sposób koń szybko wrócił do swego wtaściciela. Wtaściciel, gdy ujrzał konia nie krył zaskoczenia i zapytat ojca: Skąd wiedziat Pan, że kon pochodzi wtaśnie stąd i należy do nas? Na to ojciec odpowiedziat: Ja tego nie wiedziałem, to kon wiedziat! Ja tylko pilnowatem, żeby nie zszedt $z$ drogite.

Przypowieść ta metaforycznie ukazuje coaching jako formę niedyrektywnego wsparcia.

\section{Coaching a inne formy wspierania rozwoju i pomocy}

Profesjonalni coachowie dokładają wszelkich starań, aby wyraźnie wskazać odmienność opisywanej formy pracy od innych form wspierania jednostki, mocując ją $\mathrm{w}$ totalnej opozycji wobec kształcenia, treningu, terapii, mentoringu, szkoleń, czy poradnictwa. Ważne jest jednak by zwrócić uwagę, iż coaching korzysta ze zdobyczy różnych modeli teoretycznych (na co wskazano powyżej) i dlatego tak trudno właśnie o jednoznaczne ustalenie, czym coaching jest, a czym nie jest. Poniżej zaprezentowane zostaną inne formy pracy, a intencją autorki jest wskazanie podobieństw oraz cech różnicujących (klasyczny, czysty) coaching i inne formy pomocy.

Mentoring "występuje wtedy, gdy starszy kolega-uczeń, doradca, menedżer, lider postrzegany jako posiadający dużą wiedzę, udziela rad i przyjmuje rolę wzorca"17. Nie ma tu zatem relacji partnerskiej, natomiast występuje wyraźny podział na tego, który ma wiedzę, kompetencje i umiejętności oraz na podopiecznego, który ich nie posiada. Co nie współgra z zasadami coachingu. Mentoring dotyczy najczęściej działań, zachowań, procedur. W szkolnej rzeczywistości można go obserwować w relacjach nauczycieluczeń, uczeń starszej klasy-uczeń młodszy, nauczyciel dyplomowanynauczyciel stażysta, dyrektor- nauczyciel, pedagog-rodzic itp.

Doradztwo stanowi zaś pracę z osobą niezadowoloną z efektów swoich działań. Tutaj pojawia się kolejne podważenie zasad coachingu, bowiem pierwsza zasada mówi, iż klient jest zasobny, ma potencjał, wie. Tu doradca niejako sam rozwiązuje problemy klienta, doradza, podpowiada, sugeruje

16 Akademia Szkoleń i Coachingu ADEPTUS - http://www.adeptus.com.pl/print.php? type $=$ N\&item_id $=11$

17 KefAnn, Psychoedukacja. Coaching a inne dyscypliny, http://www.kefann.pl/art037_2_ Coaching_a_inne_dyscypliny.html, [dostęp: luty 2014/]; Z. Nieckarz, S. Celińska-Nieckarz, D. Godlewska-Werner, Psychologia coachingu biznesowego, s. 40; J. Rogers, Coaching, Gdańsk 2010, s. 20-34. 
gotowe rozwiązania. $\mathrm{W}$ coachingu rozwiązania proponuje sobie sam klient. Doradca to ten, który wie (lepiej). Występuje z pozycji eksperta - posiadającego wiedzę, której nie ma klient. Proponuje własne, uznane za najbardziej skuteczne rozwiązania. Znika tu kolejna zasada coachingu - partnerstwo, równość ról. Doradca w takim ujęciu jest zatem osobą, która wie lepiej (od samego radzącego się), co jest dla niego wskazane i dobre. Doradztwo przejawia się w szkole na wielu płaszczyznach: dyrektor-nauczyciele, nauczyciele-uczniowie, rodzic-nauczyciel, pedagog, doradca zawodowy, inny specjalista - potrzebujący pomocy. Doradztwo zawodowe, jak je określa R. Lamb, to

proces, w którym doradca zawodowy pomaga klientowi w osiągnieciu lepszego zrozumienia samego siebie $\mathrm{w}$ odniesieniu do środowiska pracy, aby umożliwić mu realistyczny wybór lub zmianę zatrudnienia lub też osiągnięcie właściwego dostosowania zawodowego ${ }^{18}$.

Terapia jest pracą z osobą, która potrzebuje usunięcia psychologicznych lub fizycznych symptomów. Klient potrzebuje uwolnienia od bólu psychicznego. Najczęstszą motywacją klienta do wejścia w terapię lub wyrażenia potrzeby porady jest chęć uwolnienia się od dyskomfortu, a nie dążenie do pożądanych celów (przynajmniej nie wprost). Nawet, jeżeli weźmiemy pod uwagę terapię krótkoterminową (zorientowaną na cele) różnica w odniesieniu do coachingu jest ogromna. Terapeuta dokonuje wielu interpretacji, stawia się w pozycji eksperta i przejmuje dużą część odpowiedzialności za efekty, jakie uzyskuje klient. Zarówno terapia jak i doradztwo wymagają raczej zrozumienia i pracy z doświadczeniami z przeszłości, w przeciwieństwie do coachingu ${ }^{19}$.

Nauczanie jest przekazywaniem wiedzy przez nauczyciela - uczniowi. Gotowy skrypt, zagadnienia, kwestia odpowiedzialności za wybór tematu pozostaje w gestii nauczyciela realizującego (także z góry ustaloną) podstawę programową. Nauczyciel występuje $\mathrm{w}$ roli wiedzącego coś, czego nie wie uczeń. W coachingu postaci te odgrywają natomiast równoznaczne role. Nauczania używa się czasem w mentoringu $\mathrm{i}$ treningu. Odwrotnie dzieje się w przypadku coachingu. Klient jest ekspertem i to klient zna odpowiedzi, a nie $\operatorname{coach}^{20}$.

18 R. Lamb, Poradnictwo zawodowe w zarysie, Zeszyty Informacyjno-Metodyczne Doradcy Zawodowego, 1999, 9, s. 9.

${ }^{19}$ KefAnn Psychoedukacja. Coaching a inne dyscypliny; Z. Nieckarz, S. Celińska-Nieckarz, D. Godlewska-Werner, Psychologia coachingu biznesowego, s. 40; J. Rogers, Coaching, s. 20-34; J. Kozielska, A. Skowrońska-Pućka, Coaching czym jest a czym nie jest? s. 19-36.

${ }^{20}$ KefAnn, Psychoedukacja. Coaching a inne dyscypliny. 
Idea tutoringu opiera się natomiast na zindywidualizowanym podejściu do studenta, ucznia, gdzie

profesor, nauczyciel-tutor jest jednocześnie nauczycielem i swego rodzaju (...) przewodnikiem, a student, uczeń aktywnym partnerem w sytuacji edukacyjnej; osoby tutora i ucznia łączy wieź pełna zaufania, która ma sprzyjać głównie rozwojowi intelektualnemu i społecznemu21.

Głównym narzędziem wykorzystywanym w tutoringu jest debata pomiędzy studentem a tutorem, choć czasem przybiera oblicze debaty między dwoma, trzema studentami. Student samodzielnie przygotowuje się do debaty analizując literaturę tematu, sporządza autorski tekst, który następnie jest recenzowany przez tutora ${ }^{22}$.

Prócz różnic zaprezentowanych powyżej, należy wskazać pewne podobieństwa wśród praktykowanych współcześnie metod. Wspomnieć choćby trzeba o podejściu skoncentrowanym na rozwiązaniach, którego paradygmat koncentracji na celu i teraźniejszości, niedyrektywności, rozwijaniu potencjału i własnych zasobów, inspirowany pracami Miltona Ericksona, podobny jest do postulatów coachingowych ${ }^{23}$. Dychotomie i wspólne cechy wyżej zaprezentowanych metod stanowią tylko tło dla nowo powstających konceptów, w których idee coachingowe odgrywają istotną rolę. Rzecz o nowych profesjach pomocowego nurtu - „architektach życia”24. Life-Design Counseling to idea promowana przez międzynarodową grupę badaczy skupionych wokół profesora Marka Savickasa, a są nimi: Laura Nota, Jerome Rossier, Jean-Pierre Dauwalder, Maria Eduarda Duarte, Jean Guichard, Salvatore Soresi, Raoul Van Esbroeck, którzy za teoretyczną podstawę proponowanego rozwiązania przyjęli konstruktywizm.

Czy w szkole bądź urzędzie w rolę klienta - czyli coachee - może wcielić się uczeń/klient (petent)? Uważam, że tak. Jeśli nie w czystej postaci, to wykorzystując styl pracy coachingowej, pozostawia całkowitą odpowiedzialność za zmianę klientowi - w szkolnych realiach uczniowi ${ }^{25}$.

21 A.I. Brzezińska, L. Rycielska, Tutoring jako czynnik rozwoju ucznia i nauczyciela, [w:] Tutoring w szkole. Między teoria a praktyka zmiany edukacyjnej, red. P. Czekierda, M. Budzyński, J. Traczyński, Z. Zalewski, A. Zembrzuska, Wrocław 2009, s. 16.

22 Tamże, s. 19-30.

${ }^{23} \mathrm{PSnR}$.

${ }^{24}$ V. Drabik-Podgórna, Doradca, coach czy „architekt życia”? O nowych zadaniach i kompetencjach w obszarze profesjonalnej pomocy, [w] Dymensje poradnictwa, s. 95-111.

${ }^{25}$ KefAnn, Psychoedukacja. Coaching a inne dyscypliny; Z. Nieckarz, S. Celińska-Nieckarz, D. Godlewska-Werner, Psychologia coachingu biznesowego, s. 40; J. Rogers, Coaching, s. 20-34. 


\section{Sześć zasad coachingu i ich szkolne egzemplifikacje}

Zasada pierwsza głosi, iż klient ${ }^{26}$ (uczeń w nomenklaturze szkolnej) jest źródłem zasobów - co w warunkach korzystania z coachingu czy wykorzystywania jego elementów w systemie edukacji będzie oznaczać, iż uczeń, zespół uczniów, rodzina, system rodzinny, nauczyciele itp. mają potencjał, możliwości pozwalające im przy dokonaniu pewnej pracy sprawniej zafunkcjonować. Zasada kolejna zakłada, iż klient ma zasoby fizyczne, psychiczne, społeczne i inne, dzięki którym może rozwiązać swój problem, osiągnąć cel, który sam określił. Sam też najlepiej zna swoje mocne strony, a za sprawą coacha dowie się, jak z nich sprawnie korzystać - do czego sprowadzają się założenia drugiej zasady skutecznego coachingu. Co warte wyraźnego zaznaczenia, zadaniem coacha nie jest dawanie rad, moralizowanie, czy kierowanie, które to czynniki wymienia się jako podstawowe dystraktory zakłócające komunikację. Jego zadaniem jest zadawanie pytań w taki sposób, aby uczestnik coachingu sam opowiadał sobie pewną narrację - narrację będącą historią jego osobistej biografii. Zdarza się, iż sam fakt „dogadania się ze sobą" przynosi znamienne efekty. Zasada trzecia określa, że w narracji klienta ważna jest trójtemporalna perspektywa czasowa. Osoba korzystająca z coachingu stanowi postać kreowania przez przeszłość, teraźniejszość i świadomie tworząca przyszłość, stąd ważne jest, by ją i jej narrację traktować całościowo. Nacisk kładzie się jednak na aspekt przyszłości27. Jenny Rogers stwierdza:

moje doświadczenie mówi, że problemom klientów w życiu zawodowym na ogół towarzyszą kłopoty w życiu osobistym. Również typy związków ukształtowanych w dzieciństwie odciskają swoje piętno na późniejszych relacjach. Coaching nie jest psychoanalizą, ale jeśli nie masz pojęcia o wcześniejszych doświadczeniach oraz o obecnym życiu osobistym klienta, prawdopodobnie nie będziesz $\mathrm{w}$ stanie pracować z nim w pełny i głęboko satysfakcjonujący sposób28.

Co w kontekście działań o charakterze edukacyjnym, wychowawczym, czy szerzej socjalizacyjnym zdaje się mieć swoje dokładne odzwierciedlenie, przejawiające się faktem, iż uczniowskie problemy rodzinne, osobiste często manifestują się w klasie szkolnej. Zasada czwarta określa bardzo istotną cechę coachingu, a mianowicie fakt, iż to zawsze klient wybiera temat. Tu

${ }^{26}$ W rzeczywistości szkolnej może nim być uczeń, nauczyciel, rodzic, dyrektor itp.

27 J. Whitmore, Coaching. Trening efektywności; M. Bennewicz, Coaching, czyli restauracja osobowości; tegoż, Coaching przebudzacz neuronów; M. Sidor-Rządkowska (red.), Coaching. Teoria; J. Bałachowicz, A. Rowicka, Nowoczesny wychowawca - tutor, s. 24-37, 37-44, 160-168; K. Blanchard, D. Shula, Coaching. Prowadź swoją drużynę; S. Thorpe, J. Clifford, Podręcznik coachingu, $2004 \mathrm{i}$ in.

28 J. Rogers, Coaching, s. 15. 
właśnie zasadza się podstawowa różnica pomiędzy coachingiem a nauczaniem czy szkoleniem. W coachingu nie istnieje z góry ustalony temat spotkania. Coaching jest odpowiedzią na aktualnie dziejące się w życiu człowieka sytuacje. Egzemplifikacją tego w systemie edukacji może być hipotetyczna sytuacja: uczeń 6 . klasy szkoły podstawowej został skierowany do pedagoga, który jest zarazem coachem. Wychowawca kierując ucznia do pedagoga, niejako z góry określił temat spotkania - brak motywacji do nauki, słabe oceny z matematyki i niewielkie szanse, w ocenie wychowawcy, na zdanie egzaminu gimnazjalnego. Jeśli $\mathrm{w}$ trakcie rozmowy $\mathrm{z}$ pedagogiem, wykorzystującym elementy coachingu, okaże się, że najważniejszą rzeczą dla ucznia jest kwestia zażegnania kłopotów osobistych, rodzinnych, zupełnie (na pierwszy rzut oka) niezwiązanych z sytuacją szkolną ucznia - coach zacznie pracę właśnie od nich. Kolejna zasada zakłada, iż klient i coach są sobie równi - pracują jak partnerzy w procesie toczącej się zmiany, odpowiedzialność za rezultat procesu spoczywa na jednym i drugim. Klient odpowiada za swoje życie i cel, do którego dąży, coach odpowiada natomiast za strukturę procesu coachingowego - jego metodykę, a podstawą ich współpracy jest bezwarunkowy szacunek. W warunkach szkolnych jest to zasada bardzo trudna do realizowania, chociażby wobec zjawiska określanego mianem przesunięcia socjalizacyjnego i faktu, iż odpowiedzialność za proces kształcenia i jego rezultat nieświadomie spoczywa po stronie nauczyciela. To on na ścieżce awansu zawodowego wskazuje liczbę promowanych uczniów, a szkoły walczą o dobre pozycje w rankingach zewnętrznych. Odpowiedzialność za proces spoczywa po stronie nauczycieli i dyrekcji, a udział uczniów w projektowaniu tematyki zajęć, planu zajęć jest znikomy. Kolejną istotną zasadą jest nieocenianie. W polskiej szkole warunek w zasadzie nie do spełnienia. Jakkolwiek znane są przykłady szkół skandynawskich (Open Learning Center), w których uczniowie oceniają sami siebie, sami też na skutek autorefleksji projektują swoje plany zajęć. Sami bowiem wiedzą najlepiej, że mają kłopoty, np. z matematyką, zatem planują ją w większym wymiarze godzin, niż np. literaturę angielską, która nie stwarza im większych trudności. Przejmują w ten sposób odpowiedzialność za swój autorski, adekwatny do potrzeb plan zajęć. Idealnie odzwierciedla to idee coachingu - przejęcie odpowiedzialności za swoje życie, odnośnie którego klient (uczeń) jest ekspertem. Ważkie zagadnienie w coachingu stanowi także kwestia szacunku - „jeśli z jakiegoś powodu nie darzysz klienta szacunkiem lub jeśli nie szanuje ciebie, efektywna współpraca jest mało prawdopodobna"29. Zasada szósta mówi, iż celem coachingu jest zmiana, ale i sam fakt dochodzenia do niej, czyli działanie.

${ }^{29}$ Tamże, s. 14. 


\section{O trudnościach i możliwościach wykorzystania coachingu w systemie edukacji. Czy coaching działa?}

Coaching w swoich wielobarwnych odsłonach (life coaching, business coaching, diet coaching, executive coaching $\mathrm{i}$ in.) znalazł się $\mathrm{w}$ ofercie dydaktycznej wielu znanych na całym świecie uczelni. Jako kierunek studiów, zajęcia obowiązkowe lub zajęcia fakultatywne, studia MBA, czy podyplomowe proponują go takie uczelnie, jak: Uniwersytet Harvarda (powołano w nim Instytut Coachingu), Amerykański Lewis University, New York University, University of California, University College Cork w Irlandii, John F. Kennedy University, Uniwersytet $\mathrm{w}$ Barcelonie, Yale University, University of Sydney i wiele innych. Wielkopolskim przykładem uczelni, które w swoich programach zadbały o aspekty coachingu jest np. Uniwersytet im. Adama Mickiewicza (Wydział Studiów Edukacyjnych, Wydział Nauk Politycznych i Dziennikarstwa) oraz reprezentanci sektora prywatnego szkolnictwa wyższego, np. Collegium Da Vinci (Wydział Studiów Edukacyjnych).

Coaching jest narzędziem wspomagania rozwojowych zmian, ale to także pewien styl bycia, styl komunikacji (aktywne, sięgające głębi słuchanie, odzwierciedlanie wypowiedzi klienta, feedforward, challenging $)^{30}$, styl radzenia sobie z sytuacjami problemowymi (wynikający z faktu, iż profesjonalni coachowie przestrzegają zasad kodeksu etycznego coacha, pracują nad samorozwojem, poddają się superwizjom i wreszcie wzmacniają swoje (i klienta) poczucie wewnątrzsterowności) ${ }^{31}$. Należy przypomnieć, iż coaching wybiega w przyszłość koncentrując się na szukaniu rozwiązań, a nie poszukiwaniu przyczyn konkretnych braków, jak dzieje się w przypadku terapii. Problem podlega $\mathrm{w}$ tym podejściu przeobrażeniu $\mathrm{w}$ cel - cel który jest celem jasno określonym, ambitnym, mierzalnym, terminowym, pozytywnie sformułowanym, pozostającym w obszarze wpływu klienta, ekologicznym (SMART) ${ }^{32}$. Celem coachingu jest wsparcie jednostki lub zespołu w przejściu ze stanu aktualnego do stanu postulowanego. Rezultatami coachingowych działań jest większa samoświadomość, precyzyjnie wyznaczone cele, optymalizacja działań, pełniejsze wykorzystanie zasobów zewnętrznych i wewnętrznych. Coach to osoba stwarzająca warunki, by proces przebiegał w sposób prawi-

${ }^{30}$ J. Whitmore, Coaching. Trening efektywności; M. Bennewicz, Coaching, czyli restauracja osobowości.

${ }^{31} \mathrm{~J}$. Rogers, Coaching.

32 J. Whitmore, Coaching. Trening efektywności; M. Bennewicz, Coaching, czyli restauracja osobowości. 
dłowy, jest facylitatorem i moderatorem spotkania. Odpowiedzialność za rezultaty coachingu spoczywa zatem na coachowanym, czyli coachee.

Istnieje szereg trudności $\mathrm{w}$ pełnym, bez zniekształceń i uproszczeń stosowaniu coachingu w szkole. Mowa o coachingu w postaci klasycznych sesji coachingowych (klient, uczeń, rodzic, nauczyciel itp. - coach). Pierwsze podstawowe utrudnienie stanowi sztywno ustrukturalizowana formuła 45-minutowych jednostek lekcyjnych, podczas których nauczyciel realizuje precyzyjne zaplanowaną podstawę programową. Nie pozwala to na zaproszenie ucznia na sesję, bo straci w ten sposób lekcję, z kolei pozostawanie ucznia po godzinach w szkole obwarowane jest innymi trudnościami formalnymi. Kolejnym problemem może okazać się fakt, iż nauczyciel konkretnego ucznia nie powinien być jego coachem. Może to bowiem powodować sytuacje, iż uczeń na przedstawione przez coacha pytania odpowiada "tak jak należy odpowiedzieć", wstydząc się przyznać, że np. czyta komiksy. Nauczycielowi języka polskiego odpowie, iż całymi wieczorami zaczytuje się w Cogito i innych magazynach dla maturzysty. Skąd zatem wziąć coacha? Kto powinien nim być w szkole? Pedagog? To także nie jest najlepsze rozwiązanie. Niestety, w polskiej szkole do pedagoga idzie się „za karę”, takie skojarzenie ról może nie przynieść oczekiwanych rezultatów procesu coachingowego. Jedną ze znamiennych zasad coachingów jest kwestia dobrowolności i chęci zmiany. Do coacha zatem nie można kierować ucznia, rodzica, nauczyciela - oddelegować go. To uczeń, rodzic, nauczyciel musi chcieć zainicjować współpracę z coachem, mając oczywiście świadomość, kim coach jest $\mathrm{i}$ jaką rolę odgrywa. Zasadne $\mathrm{w}$ takiej sytuacji byłoby informowanie uczniów, nauczycieli i rodziców, iż w szkole można skorzystać $z$ metod pracy coachingowej. Autentyczna i trwała zmiana jest dziełem osoby, która prawdziwie jej pragnie, jest do niej przygotowana, wyczekuje jej i chce zaangażować się w proces jej wdrażania. Idąc dalej, możemy powiedzieć, że „jednym z podstawowych warunków osiągnięcia efektów w coachingu - obok pełnego zaangażowania i silnej potrzeby zmiany klienta jest jego gotowość do wzięcia pełnej odpowiedzialności za własny rozwój33. Laura Ćwikła wymienia czynniki oporowe wobec wprowadzania zmian. Pierwszą ich grupę stanowi lęk.

Lęk przed zmianą, która na poziomie deklaratywnym jest bardzo oczekiwana, stanowi koncept problemowy do wychwycenia przez samego zainteresowanego. Klient bardzo często deklaruje, że bardzo mu zależy na wprowadzeniu zmian w swoje życie, na odmienieniu go, robi wszystko, co

33 L. Ćwikła, Efektywność działań w procesie coachingowym. Między deklaracją a gotowością do zmiany, [w]: Dymensje poradnictwa, s. 52. 
w jego mocy, informuje, iż próbował już wielu rzeczy itp., lecz z jakiegoś powodu mu się to nie udaje. Sytuacja taka jest oczywista, skoro zmiana, jako wartość sama w sobie, będąca fundamentalną cechą współczesności, zmusza nas do podejmowania coraz większej liczby decyzji, często w sytuacjach niepewnych, ryzykownych, o nieprzewidzianych konsekwencjach dla dalszego funkcjonowania ${ }^{34}$.

I chociaż dokonywanie zmiany jest przejawem refleksyjności, może być krokiem w kierunku rodzących się nowych problemów. Słowo problem zdaje się mieć tutaj kluczowe znaczenie, bowiem podczas gdy klient obawia się powstania nowych, nieznanych dotąd dylematów $i$ trudności, coach proponuje mu zmianę spektrum postrzegania i przetransponowanie kwestii problemowej na zadanie do rozwiązania. Zabieg taki nie jest bynajmniej jedynie zabiegiem nomenklaturowym, lecz zmianą postrzegania i perspektywy, która umożliwia stawienie czoła swoim obawom ${ }^{35}$.

Lęk przed porażką powoduje, że wiele osób żyje poniżej poziomu swoich możliwości, pragnień, aspiracji. Taki przebieg wydarzeń może mieć miejsce dlatego, że dotychczasowe zmiany nie potoczyły się dla klienta korzystnie i przyniosły niepożądane rezultaty, co w naturalny sposób wywołuje w nim - uświadomioną lub nie - obawę przed kolejną zmianą i domniemaną porażką. Jest to lęk przed nieznanym, ale skoro nie wiemy co będzie, nie znamy przyszłości - to czego się obawiamy? Rolą coacha jest uświadomić to klientom. Ważkim zagadnieniem staje się tu społeczny obraz porażki,

powielany w przekazie międzypokoleniowym, stygmatyzowanej jako przegrana, będąca powodem do wstydu. Kluczem do zmierzenia się z tą obawą jest zmiana postrzegania niepowodzeń. Porażka traktowana jako rezultat działań może stać się cennym źródłem informacji zwrotnych, wzbogacających klienta o doświadczenie przed podjęciem kolejnych starań. I jakkolwiek lęk przed porażką niezmiennie bywa źródłem frustracji, nie sposób zaprzeczyć, że jedynym niezawodnym sposobem na uniknięcie w życiu niepowodzeń jest zaprzestanie jakichkolwiek działań ${ }^{36}$.

Klienci bardzo często wskazują, iż to nie oni odpowiadają za złą sytuację, w której się znaleźli. Jej źródeł upatrują w czynnikach zewnętrznych, jak np. zły los, zły nauczyciel, zbyt trudne pytania na sprawdzianie sprawiły, że poległem. Rolą coacha jest postawienie pytań w taki sposób, by uczeń uświadomił sobie, iż niepowodzenie jest jego dziełem. Można w takiej sytuacji zapytać: ile czasu spędził przygotowując się do sprawdzianu, jak te przygotowania wyglądały, czym $\mathrm{w}$ ich czasie się autentycznie zajmowal, z czyjej pomocy mógł skorzystać, kiedy zaczął przygotowana, czy to wystar-

\footnotetext{
34 Tamże.

35 Tamże, s. 52-53.

36 Tamże, s. 53.
} 
czający czas, co zrobi inaczej następnym razem itp. W coachingu chodzi o to, by klient sam sobie odpowiedział, by to usłyszał sam od siebie. Komunikat płynący od nas samych jest komunikatem, który często przyjmujemy bijąc się $\mathrm{w}$ pierś. Kiedy natomiast nauczyciel lub rodzic poucza (często podniesionym głosem) automatyczną postawą jest opór, szukanie kontrargumentów itp.

Lęk przed zaufaniem coachowi oraz lęk przed otwarciem się na coacha, co sygnalizowano wcześniej pisząc o dylemacie szkolnych ról nauczyciel, pedagog, psycholog itp. - jest poważnym dystraktorem dla skuteczności procesu coachingowego. Podczas sesji klient powinien opowiadać bez fałszywej skromności zarówno o tym, z czego jest zadowolony, czego dokonał, jak i o tym, co odbiera jako swoją porażkę, ufając $\mathrm{w}$ pełni, że coach go nie osądzi, nie oceni (co przecież jest nierozerwalnym elementem szkolnych relacji na wielu poziomach uczeń-uczeń, uczeń-nauczyciel itp.), nie wyrobi sobie niekorzystnego zdania o nim, a nade wszystko, wedle naczelnej zasady coachingowej - zasady poufności - nie podzieli się z nikim pozyskanymi informacjami. Zaufanie $\mathrm{w}$ procesie coachingowym ma też inny wymiar, przejawia się bowiem $\mathrm{w}$ wierze coacha $\mathrm{w}$ klienta i jego potencjał. Lęk przed prawdziwym wglądem w siebie jako pogłębionym spotkaniem z "Ja", lęk przed tym co znaczący inni powiedzą na zmianę to kolejne czynniki utrudniające zmianę. Nie należy zapomnieć także o braku wiary w siebie, niskim poczuciu własnej wartości, silnie zakorzenionych przekonaniach na temat swój i świata.

Błędne oczekiwania i przekonania mogą mieć rzeczywisty wpływ na to, co się wydarzy, a samospełniające się przepowiednie, będące przewidywaniami dotyczącymi jakiegoś przyszłego zachowania lub zdarzenia, modyfikują interakcje behawioralne w taki sposób, że uzyskuje się to, czego się rzeczywiście oczekiwało ${ }^{37}$.

Dlatego też podczas coachingu warto stosować narzędzia zmiany perspektywy klienta, sprawdzać przekonania, sposoby postrzegania danej sytuacji i przyczyny zbyt długiego trwania przy nawykach i skryptach myślenia i działania, które dawno już przestały klientowi służyć.

W tym kontekście warto towarzyszyć klientowi w procesie wytwarzania $\mathrm{w}$ sobie nawyku buntowania się przeciwko niepodważalności swoich racji, gdyż tworzenie nowych zwyczajów oraz akceptacja niepewności ułatwiają przełamywanie sztywności poznawczych. Jakkolwiek truizmem jest dziś mówienie, że myśli kształtują charakter, zatrzymanie i przyjrzenie się strumieniowi myśli klienta, niejednokrotnie staje

37 L. Ćwikła za: Gerring Zimbardo (2011, s. 23), Efektywność działań w procesie coachingowym, s. 57. 
się podwaliną do zmiany tego nawyku, a ta, w połączeniu ze zmianą wewnętrznego dialogu, może stać się przyczynkiem do zmiany będącej celem procesu coachingowego ${ }^{38}$.

Kolejną grupą czynników utrudniających wprowadzanie zmian, a to przecież podwalina coachingowych zmagań, jest brak chęci do dokonania zmian, brak motywacji, osadzenie się w obecnym stanie rzeczy i uznanie go za komfortowy, brak chęci do inwestowania energii, czasu, środków, skupianie się na poszukiwaniu usprawiedliwień dla zastanego stanu rzeczy, oczekiwanie gotowych recept, porad, oczekiwanie, że zmienią się czynniki zewnętrzne i inne.

\section{O zastosowaniu coachingu w doradztwie zawodowym}

Przegląd pozycji naukowych z ostatnich lat, próbujących oddać specyfikę pomocy/wspierania/wspomagania/doradzania, pokazuje dokonującą się zmianę i przejście od poradnictwa/doradztwa zawodowego do poradnictwa konstruowania życia ${ }^{39}$. U podłoża przeobrażenia modelu pomagania leży zmiana paradygmatu. Praktyczne działania stosowane we współczesnym poradnictwie są zakotwiczone w założeniach na temat stałości istoty ludzkiej (modele cech-czynników). Należy zwrócić jednak szczególną uwagę na fakt, iż nawet takie czynniki, jak zainteresowania są mniej stabilne, niż zwykło się przyjmować. Teorie rozwojowe natomiast, określając rozwój zawodowy jako stałą sekwencję etapów, uznawały, że możliwe jest jego przewidywanie i szczegółowe planowanie ${ }^{40}$. Wobec niepewnego jutra, transnacjonalnych karier i chybotliwej teraźniejszości należy wyposażyć klientów w umiejętność samodzielnego konstruowania siebie ${ }^{41}$. Metody coachingowe na to pozwalają.

Jednym z popularnych modeli rozmowy coachingowej jest model GROW, którego nazwa stanowi skrót składający się z pierwszych liter opisujących poszczególne etapy rozmowy.

38 Tamże.

${ }^{39}$ V. Drabik-Podgórna, Doradca, coach czy „architekt życia”?; M. Savickas, Carieer Counseling, Washington $2011 \mathrm{i}$ in.

40 Tamże, s. 95-109.

${ }^{41} \mathrm{~J}$. Kozielska, Poakcesyjne migracje zarobkowe. Kontekst teoretyczno-empiryczny. Wsparcie spoteczne, Poznań, 2014; tejże, Migracyjne transnarodowe wsparcie społeczne. Kazus młodych polskich imigrantów zarobkowych, Studia Edukacyjne, 2001, 33; tejże, Młodzi polscy emigranci na globalnym rynku pracy. Migracyjne doświadczenia zawodowe w trzech perspektywach temporalnych, Rynek Społeczeństwo - Kultura, 2014, 4, s. 14-21. 
Goal - jak cel - jaki jest cel naszego spotkania?

Reality - jak rzeczywistość - gdzie jesteś teraz?

Options - jak opcje - co możesz zrobić by osiągnąć cel?

Will - czyli wola - którą opcję wybierasz dla siebie?

Według takiego modelu można zaprojektować także schemat rozmowy doradcy zawodowego z klientem, rozszerzając go o następujące kwestie: Etap I - określenie tematu spotkania; Etap 2 określenie celu - specyficznego, mierzalnego, realnego, pozytywnie sformułowanego, ekologicznego, mieszczącego się w obszarze wpływu klienta; Etap III - poznanie obecnej rzeczywistości; Etap IV - planowanie oparte na wcześniej rozpoznanych zasobach; Etap V - rozwój osobisty za sprawą zaproponowanych przez coacha ćwiczeń; Etap VI - działanie i weryfikacja poczynionych zmian, kontrola i modyfikacja poczynionych zmian oparta na autorefleksji klienta/ucznia ${ }^{42}$.

Tabela 1

Tabelaryczne ujęcie modelu GROW - kazus doradztwa zawodowego

\begin{tabular}{|c|c|c|}
\hline Etap & Co chcemy osiągnąć? & Przykłady pytań \\
\hline CEL & $\begin{array}{l}\text { Ustalamy cel, jaki chcemy } \\
\text { osiągnąć } \\
\text { Chcę wybrać przyszły } \\
\text { zawód. Chcę by X. } \\
\text { Chcę znaleźć wakacyjne } \\
\text { zatrudnienie. } \\
\text { Chcę podjąć zatrudnienie. }\end{array}$ & $\begin{array}{l}\text { Co chcesz osiągnąć? Kiedy? } \\
\text { Dlaczego jest to dla Ciebie ważne? } \\
\text { Co to zmieni? Jak wpłynie na Twoje } \\
\text { życie ta zmiana? Co Ci przyniesie? } \\
\text { Jak to wpłynie na Twoje życie? Na Twój } \\
\text { obraz siebie? Co o tej zmianie powiedzą } \\
\text { Twoi rodzice? } \\
\text { Jak wpłynie to na życie Twoich bli- } \\
\text { skich? } \\
\text { Po czym poznasz, że osiągnąłeś cel? } \\
\text { Co zyskasz jeśli to osiągniesz? } \\
\text { Co stracisz gdy tego nie zrobisz? } \\
\text { Doradca wykorzystując ten element } \\
\text { coachingu może zobrazować uczniom/ } \\
\text { klientom, jak właściwie wybrany zawód } \\
\text { wpłynie na ich życie, po czym prosi } \\
\text { o ich własne przykłady dotyczące kwe- } \\
\text { stii - dlaczego warto pracować w zgo- } \\
\text { dzie z zainteresowaniami i pasją. }\end{array}$ \\
\hline $\begin{array}{l}\text { RZECZYWI- } \\
\text { STOŚĆ }\end{array}$ & $\begin{array}{l}\text { Klient/uczeń określa jak } \\
\text { jest teraz }\end{array}$ & $\begin{array}{l}\text { Jak jest obecnie? } \\
\text { Co już zrobiłeś by osiągnąć cel? } \\
\text { Co się udało? } \\
\text { Jakie kroki podjąłeś? Które z nich oka- } \\
\text { zały się owocne? } \\
\text { Z jakich zasobów skorzystałeś? }\end{array}$ \\
\hline
\end{tabular}

42 P. Nowak, E. Hińcza, Wykorzystanie idei coachingu w doradztwie zawodowym, Studia Pedagogiczne Problemy Społeczne, Edukacyjne i Artystyczne, 2014, 24, s. 273-287. 


\begin{tabular}{|c|l|l|}
\hline Etap & \multicolumn{1}{|c|}{ Co chcemy osiągnąć? } & \multicolumn{1}{c|}{ Przykłady pytań } \\
\hline \multirow{5}{*}{ OPCJE } & Coachee wskazuje własne & Co możesz zrobić inaczej? \\
& $\begin{array}{l}\text { możliwe sposoby osiągnię- } \\
\text { cia celu. To przecież on }\end{array}$ & Czego możesz zrobić więcej? \\
& $\begin{array}{l}\text { Czego możesz robić mniej? } \\
\text { zna swoje skrypty działa- }\end{array}$ & Jak zrobiłby to Twój ulubiony bohater? \\
& nia i dobrze działające & Z czego możesz skorzystać? \\
& strategie. & Z czyjego wsparcia możesz skorzystać? \\
\hline \multirow{3}{*}{ WYBÓR } & Uczeń wybiera swój spo- & Wskazałeś kilka dróg osiągniecia celu - \\
& sób dotarcia do celu. & którą wybierasz? \\
& Podejmuje decyzję. & Jaki będzie Twój pierwszy krok? \\
& & Jak się będziesz motywował? \\
& & Co zrobisz już dziś by przybliżyć się do \\
& & celu? \\
& & Jakie zadanie domowe sobie zaprojek- \\
& tujesz? \\
\hline
\end{tabular}

Źródło: opracowanie własne.

Prezentując przykład formułowania celu spotkania i procesu, z reguły w klasycznym modelu doradztwa uczeń/klient oczekuje recepty - powiedz mi kim mam być? Zrób test, po którym dowiem się, na jaką uczelnię aplikować. Coach nie serwuje gotowych recept, nie podpowiada i nie doradza. Zadaje pytanie $\mathrm{w}$ taki sposób, by klient sam znalazł rozwiązanie i sposób na wyjście z sytuacji. M. Savickas od lat stosuje coachingowy kwestionariusz wywiadu $\mathrm{w}$ uprawianym przez siebie coachingu kariery. Pobieżny tylko przegląd ogólnodostępnych dla doradców zawodowych narzędzi, np. kwestionariusza predyspozycji czy zainteresowań zawodowych, pozwala domniemać, iż na pytania w nich zawarte uczniowie udzielać będą hipotetycznej odpowiedzi. Nigdy bowiem wcześniej nie prowadzili dużego projektu, zatem nie wiedzą jakby się zachowali, gdy np. do pracy nie przyjdzie 6 z 10 znaczących pracowników. W teście natomiast muszą udzielać odpowiedzi na takie właśnie pytania. Jak zatem na podstawie „wymyślonych” odpowiedzi prognozować profil zawodowy np. gimnazjalisty. Przywołany już M. Savickas stosuje krótki wywiad, celem wskazania zawodowych predyspozycji. Pyta rozmówcę po pierwsze, w czym może mu pomóc i jak może stać się dla niego użyteczny, dalej pojawia się pytanie o ulubioną postać z dzieciństwa, o dziecięcego bohatera czy autorytet - jego cechy. Kolejne pytania dotyczą ulubionych czasopism, seriali, programów, filmów, by skończyć na najwcześniejszych doświadczeniach z dzieciństwa i życiowym haśle (motto). Autor narracji sam opowiada wówczas, co go pasjonuje, czym się autentycznie interesuje czy szerzej - jakim jest człowiekiem. Zadaniem doradcy jest następnie, na podstawie posiadanej wiedzy (jak np. typy oso- 
bowości Hollanda, tęczowy model kariery), nakreślenie profilu zawodowego klienta. Kolejne ćwiczenie, które można wykorzystać w doradztwie zawodowym, zaprezentowała V. Drabik-Podgórna.

Należy poprosić ucznia/klienta by wyobraził sobie swoje życie jako dom. Dalej pojawiają się kolejne pytania. Twój dom jest wyjątkowy, ponieważ materiały jakich użyjesz, to Twoje zasoby: wiedza i umiejętności, zdolności i cechy osobowości, zainteresowania, pasje, wartości. Możesz go narysować...

1. Jaki to będzie dom (wysoki, niski, jednorodzinny, wieżowiec, biurowiec..., piętra, pokoje itp.)?

2. Co będzie stanowiło jego fundamenty?

3. Z czego będzie zbudowany? Z jakiego materiału będą jego poszczególne części?

4. Gdzie go zbudujesz? Co będzie go otaczać?

5. Z kim będziesz budować (sam)?

6. Jak chcesz go urządzić?

7. Jakich przeszkód obawiasz się w jego konstruowaniu?

8. Jak możesz się przygotować do ich pokonania już dziś?

9. W jaki sposób będziesz świętować kolejne etapy jego konstrukcji?

10. Jakie Twoje zasoby zapewnią Tobie zadowolenie?

11. Kim będziesz, kiedy już w nim zamieszkasz?

12. Czego potrzebujesz, aby rozpocząć konstruowanie?

13. Jaki będzie Twój pierwszy krok?

14. Kiedy go wykonasz? ${ }^{43}$

\section{O korzyściach stosowania coachingu}

We wstępie do prezentowanego tekstu wskazano na korzyści ze stosowania metod coachingowych w świecie biznesu. Coaching w oświacie także może korzystnie działać i to na kilku płaszczyznach:

Dyrektor szkoły-Nauczyciele

Nauczyciel-Nauczyciel(e)

Nauczyciel-Uczeń/Klasa

Nauczyciel-Rodzic

Rodzic-Dziecko

i wpływać nie tylko na sferę edukacji, wychowania, ale także na prywatne życie uczestników procesów coachingowych.

${ }^{43}$ V. Drabik-Podgórna, Doradca, coach czy "architekt życia”? s. 108-109. 
Agnieszka Grzymkowska w materiałach szkoleniowych ORE wskazuje:

W coachingu (...) wszystko sprowadza się do poszukiwania rozwiązań prowadzących do likwidacji luki między stanem obecnym, a stanem pożądanym. Stosowanie coachingu w szkole w zaproponowanych obszarach może mieć korzystny wpływ dla wszystkich uczestników procesu edukacji $(. . .)^{44}$.

Korzyści wynikające z wykorzystania coachingu w pracy doradców zawodowych prezentuje poniższa rycina.

\begin{tabular}{|c|c|c|}
\hline & & $\begin{array}{l}\text { Ucznlowle I Rodzice } \\
\text { (lub kllenci) }\end{array}$ \\
\hline & \multirow{2}{*}{$\begin{array}{l}\text { Nauczyclele (lub } \\
\text { pracownlcy np } \\
\text { Urzędów Pracy) }\end{array}$} & (Uczeń , Klient) \\
\hline & & $\begin{array}{l}\text { Wzmocnienie poczucia } \\
\text { koherencji }\end{array}$ \\
\hline & $\begin{array}{l}\text {-Rozwój kompetencji } \\
\text { własnych }\end{array}$ & $\begin{array}{l}\text {-Poznanie swoich } \\
\text { mocnych stron }\end{array}$ \\
\hline & $\begin{array}{l}\text {-Wzrost motywacji do } \\
\text { pracy }\end{array}$ & -Wzrost samooceny \\
\hline & - Nowa postawa wobec & do działania \\
\hline & $\begin{array}{l}\text { ucznia/klienta } \\
\text {-Profilaktyka wypalenia }\end{array}$ & $\begin{array}{l}\text {-Budowanie bliskiej relacji } \\
\text { z otoczeniem doradców }\end{array}$ \\
\hline & zawodowego & -Swiadomosć, ze \\
\hline & $\begin{array}{l}\text {-Wzrost poczucia } \\
\text { koherencji }\end{array}$ & \\
\hline & -Możliwość korzystania z & wsparcia \\
\hline & nowoczesnych metod & (Rodzlce) \\
\hline zkota idvrekcla & pracy & - Znajomość narzędzi \\
\hline -Umocnienie wizerunku- & $\begin{array}{l}\text {-Wzmocnienie relacji z } \\
\text { uczniem/klientem }\end{array}$ & $\begin{array}{l}\text { motywujacych młodzież } \\
\text { do nauki - rozwój własny }\end{array}$ \\
\hline organizacja uczaca się & -Praca w oparciu o & - nawiazanie wspótpracy z \\
\hline - Ustawiczne doskonalenie & zasoby ucznia/klienta & nauczycielem- coachem \\
\hline koncepcji kadry & -Koncentracja na & -lepszy przepływ \\
\hline -Rozwijanie kultury współpracy & $\begin{array}{l}\text { rozwiazzaniach - ni ena } \\
\text { problemach }\end{array}$ & $\begin{array}{l}\text { informacji: szkoła - } \\
\text { rodzice }\end{array}$ \\
\hline $\begin{array}{l}\text {-Moíliwost większego zgłębienia } \\
\text { istoty problemu }\end{array}$ & $\begin{array}{l}\text {-Moźliwoš́t } \\
\text { autorefleksyjnego } \\
\text { podejscie do } \\
\text { skutecznosci własnych } \\
\text { działań }\end{array}$ & $\begin{array}{l}\text {-zwiększone } \\
\text { zaangażowanie w } \\
\text { problemy dziecka i szkoły }\end{array}$ \\
\hline
\end{tabular}

Ryc. 1. Korzyści wynikające z wykorzystania metod coachingowych w doradztwie zawodowym

(źródło: opracowanie własne na podstawie A. Grzymkowska, ORE)

44 A. Grzymkowska, ORE, Coaching w pracy z zespołami nauczycielskimi https://www. google.pl/search?q=Grzymkowska, + +ORE,+ Coaching $+w+$ pracy $+z+z e s p o \% C 5 \% 82 a m i+$ nauczy cielskimi\&ie=utf-8\&oe=utf-8\&gws_rd=cr\&ei=LAOzVO_2HaLQygOa4IKQBQ [dostęp: maj 2014]. 


\section{Autorka stwierdza, że}

coaching rozpoczyna się zatem od określenia problemu, następnie problem ten zamieniany jest w cel, kolejnym krokiem jest określenie oczekiwanych rezultatów i dopiero na koniec przechodzimy do poszukiwania dostępnych rozwiązań. Coaching w oświacie uzupełnia pewną lukę. Do tej pory rozwój kadr odbywał się głównie poprzez szkolenia. Metoda coachingu może mieć wpływ na zmianę postaw, a nie tylko zwiększanie wiedzy i nabywanie umiejętności. Pomaga także, poprzez wykorzystywanie już posiadanych kompetencji, w uporządkowaniu działań. Wprowadzenie metod i technik coachingowych jako uzupełnienie podstawowych umiejętności pedagogów może stać się początkiem nowej jakości edukacji ${ }^{45}$.

Za przykład wykorzystania elementów coachingu, płynących z wykorzystania elementów psychologii pozytywnej, niech posłuży schemat często wykorzystywanych w szkole oraz przez rodziców kontraktów, które się tworzy, by następnie ich nie egzekwować i nie przestrzegać ustalonych reguł. Kontrakt psychologiczny to zbiór zasad, który obowiązuje w ciągu roku szkolnego uczniów i nauczyciela. Jest to rodzaj układu, który pozytywnie wpływa na życie w klasie, a przez to na wyniki pracy. Ważne jest, by regulaminowe zasady odnosiły się do konkretnych zachowań, były jasne i nie budziły wśród uczniów wątpliwości. Podczas wspólnego (partnerstwo, obopólna odpowiedzialność) spisywania kontraktu w podejściu coachingowym stosuje się język pozytywny zamiast negatywnego, gdyż umysł nie rozróżnia słowa „nie" (język hipnotyczny Miltona Eriksona). Pozytywnie sformułowana zasada pozbawiona zakazu lepiej wpłynie na uczniów; zamiast: „nie przeszkadzajcie na lekcjach” - uważamy na lekcjach i inne pozytywne przykłady - jemy, pijemy, żujemy gumy po lekcjach, przychodzimy punktualnie na lekcje, telefonów komórkowych i innych gadżetów elektronicznych używamy na przerwach, siedzimy na krzesłach spokojnie itp. - są to koncepty odpowiadające także coachingowemu feedforward ${ }^{46}$.

Wykorzystanie niedyrektywnych coachingowych metod w systemie edukacji i doradztwie zawodowym stanowi niewątpliwie duże wyzwanie wobec zaprezentowanych powyżej trudności. Nie jest jednak niemożliwe (coaching pojawił się w biznesie zaadaptowany ze świata sportu, zatem i w szkole może pojawić się jego kolejna odsłona), a wobec upatrywanych w coachingu korzyści jest to przedsięwzięcie kuszące, bo dobrze rokujące.

45 Tamże.

${ }^{46}$ J. Whitmore, Coaching. Trening efektywności; J. Kordziński, Nauczyciel, trener, coach, Warszawa 2013; L. Kupaj W. Krysa, Kompetencje coachingowe nauczycieli. 


\section{BIBLIOGRAFIA}

Bałachowicz J., Rowicka A. (red.), Nowoczesny wychowawca - tutor, mentor, coach, WSP TWP, Warszawa 2013.

Bennewicz M., Coaching przebudzacz neuronów, Wydawnictwo: G+J Gruner+Jahr Polska, Warszawa 2009.

Bennewicz M., Coaching, czyli restauracja osobowości, Grupa Wydawnicza Foksal, Warszawa 2013.

Bielińska I., Badania skuteczności coachingu, tekst dostępny na http://ingabielinska.com/ coaching-dla-firm/badania-skutecznosci-coachingu/ [dostęp: 10.10.15].

Blanchard K., Shula D., Coaching. Prowadź swoją drużynę ku zwycięstwu, Wydawnictwo MT Biznes, Warszawa 2009.

Brzezińska A.I., Rycielska L., Tutoring jako czynnik rozwoju ucznia i nauczyciela, [w:] Tutoring w szkole. Między teoria a praktyka zmiany edukacyjnej, red. P. Czekierda, M. Budzyński, J. Traczyński, Z. Zalewski, A. Zembrzuska, Towarzystwo Edukacji Otwartej, Wrocław 2009.

Clutterbuck D., Coaching zespołowy, Dom Wydawniczy Rebis, Poznań 2009.

Ćwikła L., Efektywność działań w procesie coachingowym. Między deklaracja a gotowościa do zmiany, [w:] Dymensje poradnictwa i wsparcia społecznego w perspektywie interdyscyplinarnej, red. M. Piorunek, Wydawnictwo Naukowe UAM, Poznań 2015.

Drabik-Podgórna V., Doradca, coach czy "architekt życia”? O nowych zadaniach i kompetencjach w obszarze profesjonalnej pomocy, [w:] Dymensje poradnictwa i wsparcia społecznego w perspektywie interdyscyplinarnej, red. M. Piorunek, Wydawnictwo Naukowe UAM, Poznań 2015.

Grzymkowska A., ORE, Coaching w pracy z zespołami nauczycielskimi https://www.google. $\mathrm{pl} /$ search?q=Grzymkowska,+ORE,+Coaching+w+pracy+z+zespo $\%$ C5\%82ami+nauc zycielskimi\&ie=utf-8\&oe=utf-8\&gws_rd=cr\&ei=LAOzVO_2HaLQygOa4IKQBQ [dostęp: maj 2014].

ICC - http:/ / encyklopediacoachingu.pl/haslo53, [dostęp: luty 2015].

ICF - coaching http://icf.org.pl/pl79,coaching.html [dostęp: luty 2014].

KefAnn, Psychoedukacja. Coaching a inne dyscypliny, http://www.kefann.pl/art037_2_ Coaching_a_inne_dyscypliny.html, [dostęp: luty 2014/].

Kordziński J., Nauczyciel, trener, coach, ABC Wolters Kluwer Business, Warszawa 2013.

Kozielska J., Poakcesyjne migracje zarobkowe. Kontekst teoretyczno-empiryczny. Wsparcie społeczne, Wydawnictwo Naukowe UAM, Poznań 2014.

Kozielska J., Migracyjne transnarodowe wsparcie społeczne. Kazus młodych polskich imigrantów zarobkowych, Studia Edukacyjne, 2014, 33.

Kozielska J., Młodzi polscy emigranci na globalnym rynku pracy. Migracyjne doświadczenia zawodowe w trzech perspektywach temporalnych, Rynek - Społeczeństwo - Kultura, 2014, 4 .

Kozielska J., Coaching w edukacji, Uczyć Lepiej, 2015/2016, 1.

Kozielska J., Skowrońska-Pućka A., Coaching czym jest a czym nie jest? O możliwościach wykorzystania coachingu jako niedyrektywnej formy wspierania w systemie edukacji, [w:] Dymensje poradnictwa $i$ wsparcia społecznego w perspektywie interdyscyplinarnej, red. M. Piorunek, Wydawnictwo Naukowe UAM, Poznań 2015.

Kozielska J., Skowrońska-Pućka A., O możliwościach wykorzystania coachingu w edukacji, Uczyć Lepiej, 2013/2014, 5. 
Kupaj L., W. Krysa, Kompetencje coachingowe nauczycieli. Jak rozwijać potencjał ucznia w szkole, Wydawnictwo Wolters Kluwer, Warszawa 2014.

Lamb R., Poradnictwo zawodowe w zarysie, Zeszyty Informacyjno-Metodyczne Doradcy Zawodowego, 1999, 9.

Nieckarz Z., Celińska-Nieckarz S., Godlewska-Werner D., Psychologia coachingu biznesowego, Harmonia Universalis, 2013, 11.

Nowak P., Hińcza E., Wykorzystanie idei coachingu w doradztwie zawodowym, Studia Pedagogiczne Problemy Społeczne, Edukacyjne i Artystyczne, 2014, 24.

Podgórny M., Coaching jako forma wspierania procesu wiedza osobista, [w:] Dymensje poradnictwa $i$ wsparcia społecznego w perspektywie interdyscyplinarnej, red. M. Piorunek, Wydawnictwo Naukowe UAM, Poznań 2015.

Rogers J., Coaching, Gdańskie Wydawnictwo Psychologiczne, Gdańsk 2010.

Savickas M., Carieer Counseling, American Psychological Association, Washington 2011.

Sidor-Rządkowska M. (red.), Coaching. Teoria, praktyka, studia przypadków, Wydawnictwo Wolters Kluwer SA, Warszawa 2009.

Thorpe S., Clifford J., Podręcznik coachingu, Dom Wydawniczy Rebis, Poznań 2004.

Whitmore J., Coaching. Trening efektywności, G+J Gruner+Jahr Polska, Warszawa 2009.

Wróblewska W., Konsekwencje zatożeń koncepcji edukacji ustawicznej dla autoedukacji. 2006; tekst dostępny na: http://www.e-mentor.edu.pl/artykul/index/numer/17/id/356/ [dostęp: maj 2015].

Zemełka A., Coaching jako niedyrektywna forma wsparcia rozwoju - inspiracje i perspektywy, [w:] Dymensje poradnictwa i wsparcia spotecznego w perspektywie interdyscyplinarnej, red. M. Piorunek, Wydawnictwo Naukowe UAM, Poznań 2015. 